\title{
Musculoskeletal disorders among preschool teachers
}

\author{
Jera Gregorc, Mira Dolenc \\ University of Ljubljana, Faculty of Education, Kardeljeva ploščad 16, 1000 Ljubljana, Slovenia \\ jera.gregorc@pef.uni-lj.si
}

\begin{abstract}
Introduction: The profession of pre-school teacher (PST) is physically and mentally demanding and thus poses a risk to musculoskeletal disorders. The purpose of the study is therefore to determine how often musculoskeletal disorders occur among PST, which parts of the body are most affected, and to analyze whether there is a connection between pain perception and the risk factors. Methods: The research has included 155 PST from different kindergartens in the Central Slovenian region, who have answered questions from the reconstructed Cornell Musculoskeletal Discomfort Questionnaires CMDQ (German version: Kreuzfeld et al., 2016). The questionnaire was divided into 3 sections. The first part covered demographic questions, the second questions about stress and frequency and intensity of motor/sport activities, and the third part was a selfevaluation assessment of muscle and joint pain. Data were processed with the statistical package SPSS - 22.o. Descriptive and inferential statistics were used (Hi-square test of equal probabilities, t-test for independent samples, and bivariate correlation analysis). Results: We found out that more than half of PST detect musculoskeletal disorders, most commonly in the lower back (52\%). PST more frequently and intensely perceive problems in the neck, shoulders and upper and lower back than in the arms or knees. We also found that those PST who evaluate their work more stressfully have more problems with muscle and joint pain. Among the most problematic pain-relieving activities, PST emphasized leaning, lifting of children, sitting on children's chairs and squatting. Discussion and conclusions: Based on the data obtained, we believe it would be reasonable to offer PST of biomechanics education and training and the use of proper load-lifting techniques, to make ergonomic adjustments in the playroom, and to carry out shorter work-appropriate exercise programs.
\end{abstract}

Keywords: musculoskeletal disorders, preschool teacher, risk factors 


\section{Introduction}

The term musculoskeletal disorders (MSDs) refers to any discomfort, problem, or pain in the musculoskeletal system (Korhan and Memon, 2019). Joint and back pain are the most commonly self-reported impairments to health among the population of Slovenia and other developed parts of the world (NIJZ, 2014). The prevalence of lifelong back pain is 70 to 80 percent, and the prevalence is 25 to 45 percent in one year. At any given time, 15 to 20 percent of people experience back pain (Vengust, 2014). According to the World Health Organization, as many as $20 \%$ to $30 \%$ of people in the world live with muscle and joint pain, with lower back pain predominating (WHO, 2019).

Risk factors for the emergence of MSDs are different and can act alone or in combination (Voglar and Šarabon, 2014). We roughly divide them into three groups (Voglar and Šarabon, 2014; Zamri et al., 2017; Jaafar and Rahman, 2017): personality, psychosocial, and physical. Given that the nature of the educator's work is intertwined with all three groups of risk factors, it is possible to conclude that educators often have MSDs. Physical risk factors are most commonly associated with back pain due to the lifting and carrying children as well as moving furniture and sports equipment (Doan et al., 2017). Psychosocial risk factors are associated with educators' occupations due to time pressures, meeting children's needs, coping with conflict situations, working with children's parents, and maintaining positive interpersonal relationships during the simultaneous employment of an educator and an assistant ( $\mathrm{Ng}$ et al., 2019). Working with children requires responsibility, a lot of energy, attention, alertness, sensitivity, and empathy, and so both stress and burnout occur among educators (Sottimano et al., 2018). However, personality risk factors do not represent significantly different adjustments and treatments as in other occupations.

Frequency indices, which show the number of cases of absence from work due to diseases of the musculoskeletal system and connective tissue, were slightly lower in the education sector until 2013 compared to all other business activities, and from 2014 up to and including 2018, they exceeded the values applying to all employees in Slovenia (National Institute of Public Health, 2019). In a systematic review of the literature, Erick and Smith (2011) found that the prevalence rate of MSDs among teachers and educators ranges between $40 \%$ and $95 \%$. Among the most endangered body segments are injuries to the back, neck, and upper extremities.

Due to the prevalence of MSDs and growing problems in the education sector, and due to the simultaneous and intertwined risk factors for the development of MSDs among educators in this study, we wanted to find out how often and how intensely educators feel pain in muscles and joints, which parts of the body are most often affected and what the connection is of perceived pain with various risk factors. 


\section{Methods}

\section{A sample of respondents}

The sample of respondents was non-specific. The study involved 155 educators of pre-school children from various kindergartens in Slovenia, who responded to the invitation to participate. Among them, 95.5\% were women, and $4.5 \%$ were men. The breakdown of the age of the respondents was as follows: $26.5 \%$ of the surveyed educators were aged between 20 and $30,34.8 \%$ were between 31 and 40 , and $38.7 \%$ were aged 41 and over. $51.6 \%$ of the surveyed educators had been working from o to 10 years, $28.4 \%$ from 11 to 20 years, $8.4 \%$ from 21 to 30 years, and $11.6 \%$ from 31 to 40 years. More than half of the respondents, or rather $62.6 \%$, worked in the second age group last year, while $37.4 \%$ worked in the first age group.

\section{A sample of variables}

The sample of variables represents a combination of three sets of questions. We compiled the first two sets ourselves, while the third represents a reconstruction of the CMDQ questionnaire (Cornell Musculoskeletal Discomfort Questionnaires) (German version: Kreuzfeld et al., 2016). The first part contained demographic variables (gender, age, job, the total number of years in education, the age group in which they were employed in the last year), the second part contained questions about the assessment of job satisfaction, feelings of stress and physical activities, while the third part covered questions on the assessment of musculoskeletal disorders (perceptions of pain in individual parts of the body, and the activities in which pain is felt as well as the patient's sick leave).

\section{The organization and process of data collection}

The survey questionnaire was sent by post in-line with prior arrangements with the kindergartens' management. The educators participated in the research anonymously and voluntarily. In the end, the completed questionnaires were collected, and the data was entered into a computer. The entire process of data collection and processing took place anonymously.

\section{Methods of data processing}

The collected data was processed with the IBM SPSS Statistics 25 software package (Statistical Package for The Social Science). Descriptive statistics (averages, standard deviations, asymmetry and flatness coefficients, minima, maxima) and inference statistics (Hi-square test of equal probabilities, t-test for independent samples, as well as bivariate correlation analysis) were used for processing. 


\section{Results}

We will first present the frequency and intensity of MSD educators in our sample. Then a set of questions about satisfaction, fatigue, and stress at work as well as a set about the physical activity of educators. Finally, we will show the connection between them.

\section{The frequency and intensity of MSD among educators}

Table 1: A self-assessment of the frequency and intensity of MSD pain in different parts of the body among educators.

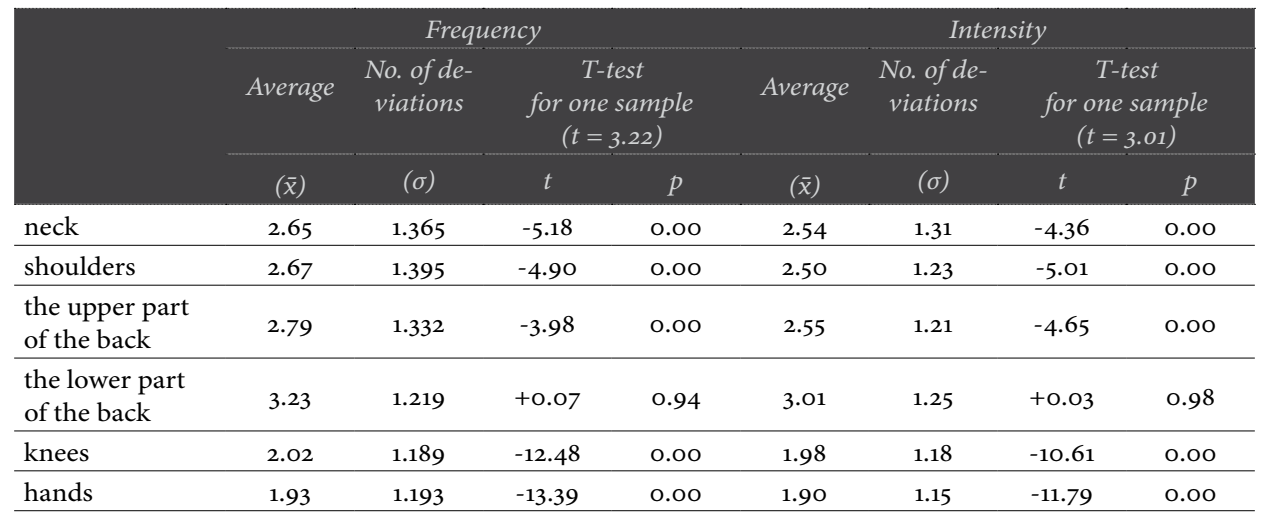

Legend: $\bar{x}$ - average value on a five-point scale, $\sigma$-standard deviation,

$t$ - $t$-test value; $p$-statistical insignificance $(p \leq 0.05)$

Educators assessed the frequency and intensity of pain in each part of the body on a five-point scale. Table 1 shows that, on average, in the last year, they experienced the lowest frequency and intensity of knee and arm pain, followed by neck and shoulder pain. Both the frequency and intensity of pain is greatest in the upper and lower back. The frequency and intensity of pain are statistically and significantly different from the average in all parts of the body except the lower back, which means that educators statistically and typically most often and most intensely feel pain and discomfort in the lower back.

\section{Satisfaction, fatigue, and stress}

Educators were then asked about satisfaction, fatigue, and stress in the workplace. We found that the vast majority are satisfied, or rather $94.9 \%$ of educators are very satisfied or satisfied with their work. The average value on the 5-point satisfaction scale is 4.46 , with a standard deviation of 0.65 . An analysis of the questions related to fatigue shows that $63.8 \%$ of educators are often and occasionally tired at work, while $29 \%$ are rarely tired. The average value on the 5-degree fatigue scale is 3.12, with a standard deviation of 0.93 . The analysis of questions about stress shows that $44.5 \%$ of educators experience the work of an 
educator as moderately stressful, $29.7 \%$ quite stressful, $16.1 \%$ slightly stressful, and $8.4 \%$ very stressful. $1.3 \%$ of educators do not experience work as stressful.

\section{Physical activity}

Analysis of the data shows that $58.0 \%$ of educators are often or very often physically active, while $41.9 \%$ are occasionally, rarely, or never physically active. In $51.0 \%$ of the respondents, the intensity of exercise is medium, in $31.3 \%$ it is high or very high, while in $\mathbf{1 8 . 7 \%}$ it is low or very low. From the data analysis, we can also determine the assessment of the frequency and intensity of the physical activity of the educators, namely on a 5-point scale where the frequency is estimated with $\mathrm{x}=3.70(\sigma=0.90)$ and the intensity $\overline{\mathrm{x}}=3.13 \sigma=0.84)$.

\section{Analysis of the relationship between the frequency and intensity of MSD with selected risk factors}

We discovered an association between the assessment of the experience of stress and the frequency of pain perceived in different parts of the body. We found that there was a statistically significant, weak positive association (at a characteristic level of $\mathrm{p}<0.01$ ) between the assessment of workplace stress and the frequency of perceived problems or discomfort in the neck $\left(r_{x}=0.272\right)$, in the shoulders $\left(r_{x}=0.301\right)$, in the upper back $\left(r_{x}=0.312\right)$, in the lower back $\left(r_{x}=0.289\right)$, in the knees $\left(r_{x}=0.324\right)$ and in the arms $\left(r_{x}=0.354\right)$. With an increase in the feeling of experiencing stress, the perception of problems in the neck, shoulders, upper and lower back, knees, and arms are also statistically significantly more frequent. Relationships between physical activity and intensity or rather the frequency of pain was not confirmed. Analysis of t-test results for dependent samples $(t=1.839, \mathrm{p}=0.068)$ also did not reveal differences in the intensity and frequency of pain between educators of the first and second age groups.

\section{Discussion}

In the research, we wanted to analyse the frequency and the degree of intensity of pain in individual parts of the body and to determine a possible connection between these and the experience of stress, physical activity, and the age of children where the educators are employed.

Based on their own self-assessment, educators evaluated the frequency and intensity of pain they perceived in individual parts of the body over the past twelve months. $91.6 \%$ of educators noticed pain in the lower back, $76.8 \%$ in the upper back, $75.5 \%$ in the neck, $74.2 \%$ in the shoulders, $53.5 \%$ in the knees, and $48.4 \%$ in the arms. Compared to other studies (Ng et al., 2019; Converso et al., 2018; Koch et al., 2015), educators in our study expressed similar or more frequent, but more intense pain. Converso et al. (2018) found that when working with children, educators most often experience pain in the upper back (84\%), followed by the neck (75.6\%), lower back (56.3\%), shoulders (49.6\%) and 
the knees (38.7\%). Sottimano et al. (2018) pointed out that $63.3 \%$ of educators have cervical pain and $67.5 \%$ lumbosacral pain. Koch et al. (2015) found aut that $40 \%$ of educators have lower back pain, followed by neck and shoulder pain. Pirbalouti et al. (2017) found that $30.5 \%$ of educators have pain in the lower back and slightly less in the neck and shoulders. With additional analysis, we found in our sample of educators that the frequency and intensity of lower back pain were statistically and significantly predominant over other parts of the body. Although the causes of pain cannot be found exclusively in the work environment, as they are also influenced by personality and other risk factors, work in kindergarten still involves quite a few psychosocial (Sottimano et al., 2018; Converso et al., 2018) and physical (Mayer et al., 2012) risk factors. An analysis of our survey data showed that as many as $67.6 \%$ of educators believe that lower back pain is related to their work, and a good half (52.3\%) believe that the work environment is the cause of upper back pain. Regarding pain in the neck, shoulders, arms, and knees, however, most educators believe that the cause of them does not come from the work they do.

In the second part, we determined the level of satisfaction, fatigue, and experience of stress at work. All three factors are classified as psychosocial risk factors for MSD (Hauke et al., 2011). The results of the survey showed that as many as $94.9 \%$ of educators are satisfied or very satisfied at work, so we believe that the factor of satisfaction at work could not be defined as one of the risk factors for MSD among educators. On the other hand, as many as $70.3 \%$ of educators are occasionally, often, or very often tired at work. Fatigue is shown in a decrease in efficiency and functionality and in a decrease in work motivation and an increased feeling of being overloaded. Fatigue can disrupt the functioning of biological functions and the mental state of the personality (Balantič et al., 2016). Therefore, fatigue can also contribute to a greater psychological burden on employees.

In the third part, we determined the frequency and intensity of the physical activity of educators. Various studies emphasize the importance of physical exercise and its preventive and curative impact on MSD (Chatzitheodorou et al., 2007; Erick and Smith, 2013; Kim et al., 2015; Rošker et al., 2014; Voglar and Šarabon, 2014). We found that $58.0 \%$ of educators are often or very often physically active, and $41.9 \%$ are occasionally, rarely, or never physically active.

In the last part, we examined the possible connections between selected risk factors (physical inactivity, stress, fatigue, type of work) with the frequency and intensity of MSD. We found a weak positive association between the experience of stress and the frequency and intensity of pain in some parts of the body. We were unable to confirm a negative or positive association between physical activity and the frequency and intensity of pain. We also failed to confirm a connection with the type of work or rather the age group of children. Given the nature of work in the first age group, which frequently involves lifting children to changing tables, highchairs, cribs, and generally more assistance in meeting children's basic needs, we expected educators working in the 
first age group to have more problems with muscle and bone pain. Converso et al. (2015), who examined differences between first and second age educators in psychophysical health, found that first age educators are more likely to complain about milder forms of MSDs.

\section{Conclusions}

A synthesis of the results directs us to consider the reasons for an increase in the presence of MSD among educators. Further research and comparisons in relation to the rise of MSDs in comparable occupations are necessary. It would make sense to research what is known about preventive measures and their degree of compliance.

\section{References}

BALANTIČ, Z., POLAJNAR, A. and JEVŠNIK, S., 2016. Ergonomija v teoriji in praksi. Ljubljana: Nacionalni inštitut za javno zdravje.

CONVERSO, D., VIOTTI, S., SOTTIMANO, I., CASCIO, V. and GUIDETTI, G., 2018. Musculoskeletal disorders among preschool teachers: analysing the relationships among relational demands, work meaning, and intention to leave the job. BMC Musculoskeletal disorders, vol. 19, no. 156, pp. $1-8$.

CONVERSO, D., VIOTTI, S., SOTTIMANO, I., CASCIO, V. and GUIDETTI, G., 2015. Work ability, psycho-physical health, burnout, and age among nursery school and kindergarten teachers: a cross-sectional study. La Medicina del lavoro, vol. 106, no. 2, pp. 91-108.

DOAN, J., AWOSOGA, O., PROVOST, T., BLINCH, J. and HUDSON, J., 2017. Perceived affordances and postures for lifting in child care. Theoretical issues in ergonomics science, vol. 18, no. 5, pp. 422-432.

ERICK, P.N. and SMITH, D.R., 2011. A systematic review of musculoskeletal disorders among school teachers. BMC musculoskeletal disorders, vol. 12, no. 260, pp. 1-11.

ERICK, P.N. and SMITH, D.R., 2013. Musculoskeletal disorder risk factors in the teaching profession: a critical review. OA musculoskeletal medicine, vol. 1, no. 3, pp. 1-10.

HAUKE, A., FLINTROP, J., BRUN, E. and RUGULIES, R., 2011. The impact of work-related psychosocial stressors on the onset of musculoskeletal disorders in specific body regions: a overview and meta-analysis of 54 longitudinal studies. Work \& stress, vol. 25, no. 3, pp. 243-256.

JAAFAR, N.A'T. and RAHMAN, M.N.A., 2017. Review on risk factors related to lower back disorders at workplace. Materials Science and Engineering, vol. 226. https://doi.org/10.1088/1757-899X/226/1/012035 
KIM, D., CHO, M., PARK, Y. and YANG, Y., 2015. Effect of an exercise program for posture correction on musculoskeletal pain. Yournal of physical therapy science, vol. 27, no. 6, pp. 1791-1794.

KOCH, P., STRANZINGER, J., NIENHAUS, A. and KOZAK, A., 2015. Musculoskeletal symptoms and risk of burnout in child care workers - a cross sectional study. PLoS ONE, vol. 10, no. 10, pp. 1-14.

KORHAN, O. and MEMON, A.A., 2019. Work-related musculoskeletal disorders. Available from: https://www.intechopen.com/books/work-related-musculoskeletal-disorders/introductory-chapter-work-related-musculoskeletal-disorders

KREUZFELD, S., SEIBT, R., KUMAR, M., RIEGER, A. and STOLL R., 2016. German version of the Cornell musculoskeletal discomfort questionnaire (CMDQ): translation and validation. J Occup Med Toxicol (London, England), vol. 11, no. 13 .

MAYER, J., KRAUS, T. and OCHSMANN, E. 2012. Longitudinal evidence for the association between work-related physical exposures and neck and/ or shoulder complaints: a systematic review. Int Arch Occup Environ Health. vol. 85, pp. 587-603.

NACIONALNI INŠTITUT ZA JAVNO ZDRAVJE, 2014. Bolezni kostno-mišičnega sistema. Available from: https://www.nijz.si/sl/bolezni-kostno-misicnega-sistema

NG, Y.M., VOO, P., and MAAKIP, I., 2019. Psychosocial factors, depression, and musculoskeletal disorders among teachers. BMC Public Health, vol. 19:234.

PIRBALOUTI, M.G., SHARIAT, A., SANGELAJI, B., TAGHAVI, M. and KAMALIYEH, N.G., 2017. Prevalence of musculoskeletal disorders and its relation to depression among workers in kindergarten. Work, vol. 58, no.4, pp. 519-525.

ROŠKER, J., KOCJAN, A. and ŠARABON, N., 2014. Pomen gibanja in gibalna terapija pri bolečini v spodnjem delu hrbta. In: ČEBAŠEK, Z., ed. Bolečina $v$ spodnjem delu hrbta: struktura, funkcija, ergonomija in gibalna terapija. Koper: Univerza na Primorskem, Inštitut Andrej Marušič, pp. 143-171.

SOTTIMANO, I., GUIDETTI, G., CONVERSO, D. and VIOTTI, S. (2018). We cannot be »forever young «, but our children are: a multilevel intervention to sustain nursery school teachers' resources and well-being during their lond work life cycle. PLoS ONE, vol. 13, no. 11, pp. 1-17.

VENGUST, R., 2014. Bolečina v spodnjem delu hrbta in najpogostejše bolezni ledvene hrbtenice. In: ČEBAŠEK, Z., ed. Bolečina v spodnjem delu hrbta: struktura, funkcija, ergonomija in gibalna terapija. Koper: Univerza na Primorskem, Inštitut Andrej Marušič, pp. 59-68. 
VOGLAR, M. and ŠARABON, N., 2014. Bolečina v spodnjem delu hrbta pri fizično obremenjujočem delu. In: ČEBAŠEK, Z., ed. Bolečina $v$ spodnjem delu hrbta: struktura, funkcija, ergonomija in gibalna terapija. Koper: Univerza na Primorskem, Inštitut Andrej Marušič, pp. 91-109.

WORLD HEALTH ORGANIZATION, 2019. Musculoskeletal conditions. Available from https://www.who.int/news-room/fact-sheets/detail/musculoskeletal-conditions

ZAMARI, E.N., MOY, F.M. and HOE, V.C.W., 2017. Association of psychological distress and work psychosocial factors with self-reported musculoskeletal pain among secondary school teachers in Malaysia. Plos One, vol. 12 , no. 2 . 